\title{
MULTINATIONAL FIRMS: \\ RECONCILING THEORY AND EVIDENCE
}

\author{
James R. Markusen \\ Keith E. Maskus \\ Working Paper 7163 \\ http://www.nber.org/papers/w7163 \\ NATIONAL BUREAU OF ECONOMIC RESEARCH \\ 1050 Massachusetts Avenue \\ Cambridge, MA 02138 \\ June 1999
}

Prepared for the NBER conference "Topics in Empirical International Economics", a Festschrift in Honor of Robert E. Lipsey. Markusen's portion of this research was funded under a grant from the National Science Foundation though the National Bureau of Economic Research. The authors thank David Carr and Rebecca Neumann for data work and estimation, and thank Ann Harrison for useful and insightful comments. All opinions expressed are those of the authors and not those of the National Bureau of Economic Research.

(C) 1999 by James R. Markusen and Keith E. Maskus. All rights reserved. Short sections of text, not to exceed two paragraphs, may be quoted without explicit permission provided that full credit, including $\mathbb{C}$ notice, is given to the source. 
Multinational Firms: Reconciling Theory and Evidence

James R. Markusen and Keith E. Maskus

NBER Working Paper No. 7163

June 1999

JEL No. F12, F23

\section{ABSTRACT}

An important component of Robert Lipsey's work has been his research on multinational firms, and his careful documentation of their behavior in terms of production and intra-firm trade. In this paper, we extend recent theory referred to as the "knowledge-capital model", which simultaneously generates motives for both horizontal and vertical multinational production. We use this model to derive predictions about foreign affiliates' pattern of production for local markets versus production for exports as functions of country characteristics such as market sizes, size differences, and relative endowment differences. These predictions are then taken to data on affiliate production and trade. Results confirm several hypotheses. The ratio of production for export sales to production for local sale by affiliates of foreign multinationals depends negatively on market size, investment and trade costs in the host country, and positively on the relative skilled-labor abundance of the parent country (skilled-labor scarcity of the host country).

James R. Markusen

Department of Economics

University of Colorado

Boulder, CO 80309-0256

and NBER

james.markusen@colorado.edu
Keith E. Maskus

Department of Economics

University of Colorado

Boulder, CO 80309-0256

keith.maskus@colorado.edu 


\section{1. $\quad$ Introduction}

An important component of Robert Lipsey's research has involved the study of direct foreign investment and often the relationship between investment and trade. From our point of view, this research is of major importance, and our first task in our paper is to explain why.

The field of international trade developed in the "modern" era as largely a study of trade in goods. Mundell (1957) wrote an important article in which he noted that trade in goods and factors were substitutes, perhaps suggesting that there is little point in expanding our theory to include trade in factors: the same equilibrium in terms of commodity prices, factor prices, and welfare can be achieved by trading either goods or factors. Only much later was it noted that Mundell showed this in the context of an extremely special case, namely a two-by-two Heckscher-Ohlin model with zero trade costs in both goods and factors. Positive analyses showed a wide variety of circumstances in which trade in goods and factors are complements (Markusen 1983, Wong 1986, Markusen and Svensson 1985, Ethier and Svensson 1986, and Neary 1995). Normative analyses showed that the effects of policy often depend crucially on what is traded (Brecher and Alejandro 1977, Bhagwati and Brecher 1980, Dick 1993).

Although it had many antecedents (e.g., Kemp 1969, Melvin 1969, Linder 1961), an industrial-organization (IO) approach to trade was developed in the 1980's. This incorporated elements of imperfect competition, increasing returns to scale and product differentiation into generalequilibrium trade models. Yet this new theory, however welcome, was largely disjoint from the study of multinational enterprises. Firms in the trade-IO literature are typically single-plant production units with all firm activities in a single location. This is rather odd insofar as most of the firms which fit the general facts and paradigms of the IO approach to trade are indeed multinationals with production 
plants in several countries. Research on multinationals was certainly produced, but it was often (at best) partial equilibrium in nature and focused on individual firms rather than on explaining the pattern of direct investment in relation to country and industry characteristics.

Robert Lipsey is a distinctive individual in that he apparently ignored this allocation of trade, national firms, and general equilibrium to trade theory and multinational firms to the international business studies. Bob wrote a number of important articles in which he related the pattern of direct investment by multinational firms to national characteristics and to trade flows. This work presented researchers with a comprehensive and challenging set of "stylized facts" to explain. His research helped make it clear that multinationals had to be integrated into both trade theory and the empirical analysis of trade and investment flows.

The work by Lipsey which most clearly relates to this paper includes the following. Two early papers with Merle Yahr Weiss examined determinants of foreign production and exports (Lipsey and Weiss, 1981, 1984). During the same period Lipsey developed a long co-authorship with Irving Kravis, looking at the determinants of the competitiveness of multinational firms and how these firms affect other variables of interest, such as domestic employment (Kravis and Lipsey, 1982, 1988, 1992, and Lipsey and Kravis, 1987). Single-authored papers on determinants of inward and outward investment and the internationalization of production include Lipsey $(1988.1989,1993,1995)$. A series of other papers was the result of collaboration with Magnus Blomstrom, in some cases with other co-authors (Blomstrom and Lipsey, 1989, 1993, Blomstrom, Kravis, and Lipsey, 1988, Blomstrom, Lipsey, and Kulchycky, 1998, Blomstrom, Lipsey, and Ohlsson, 1990, and Lipsey, Blomstrom and Ramstetter, 1995). This body of work provides a tremendous volume of empirical evidence on direct investment and trade, that needs to be reconciled with formal theory. 
A few attempts to develop a formal general-equilibrium theory of multinationals firms developed during the early 1980's. Helpman (1984) had a model in which production involved two activities, one capital intensive and one labor intensive, which could be geographically separated. Markusen (1984) took a rather different approach, assuming the existence of firm-level (as opposed to plant-level) scale economies arising from the joint-input nature of knowledge capital across geographically separated production facilities. Helpman's model captured the notion of verticallyintegrated firms, but allowed no investments to take place between very similar countries, which is clearly counter to empirical fact. Markusen's model captured the notion of horizontally-integrated firms that undertake the same activity in multiple countries, but excluded any motive for vertical specialization. Theoretical refinements of these ideas can be found in Helpman (1985), Horstmann and Markusen (1987, 1992), Brainard (1993a), Markusen (1997), Markusen and Venables (1998), and a survey is found in Markusen (1995).

During the same period in which some of this formal theory was developing, a large body of empirical work developed relating direct investment to country and industry characteristics, much of this by Robert Lipsey alone or with various co-authors as just noted. It quickly became clear that the overwhelming proportion of direct investment occurs among the similar, high-income developed countries, not between dissimilar countries. "North-north" investment dominates "north-south" investment even after correcting for income levels and other determinants. At a superficial level, horizontal, multi-plant models fit the data better than vertical-specialization models, which do not predict direct investment among similar countries.

Formal econometric reconciliation or testing of the theories with the evidence was slow in coming. Two important papers by Brainard (1993b, 1996) confirmed the casual observation that 
similarity rather than differences between countries in terms of size and relative endowments is closely related to the level of direct investment relative to trade. These papers provide additional support to the "horizontal" view that firm-level scale economies rather than factor-intensity differences between activities provides the more important explanation of direct investment. Yet subsequent to 1987, the year of her data sample, a boom in direct investment to developing countries emerged. This suggested that perhaps it was unmeasured investment barriers that accounted for the low levels of direct investment to these countries. Carr, Markusen, and Maskus (1998) estimate a model that integrates both horizontal and vertical motives for direct investment on 1986-94 panel data and find support for that integrated approach. Complementary work by Ekholm (1995, 1997, 1998a,b) supports the findings of Brainard and Carr, Markusen, and Maskus, and adds convincing evidence about the importance of intra-firm trade in knowledge-intensive headquarters services. Of relevance to the present study, recent empirical work that focusses on the relationships between direct investment and trade flows (particularly intra-firm), such as whether or not trade and investment are in some sense complements or substitutes, includes papers by Blonigen (1997, 1998), Swenson (1998), and Smith (1998).

The objective of this paper is to extend this inquiry by decomposing foreign affiliate production data into sales to the host-country market and export sales. We first develop and extend existing theory from Markusen (1987) and Carr, Markusen and Maskus (1998) (henceforth CMM) to generate separate predictions as to how local sales versus export sales should be related to parentcountry and host-country characteristics. This approach will attempt to get at the horizontal versus vertical distinction that is not explicitly considered in CMM. These theoretical predictions are then taken to the data. 
Results fit well with the theoretical hypotheses. Local sales of foreign affiliates are strongly dependent on market size and trade costs into the host country. Skilled-labor abundance between the parent and host country is only weakly related to local affiliate sales in both economic and statistical terms. Export sales are weakly related to market size and to host-country trade costs. They are strongly related to the skilled-labor-endowment differences of the parent and host countries, and strongly related to an interaction term between skill differences and country size: exports by affiliates are particularly important when the parent is both skilled-labor abundant and small (e.g., Sweden, The Netherlands, Switzerland). Both local sales and export sales are strongly negatively related to a host-country investment barrier (cost) index.

The ratio of exports to local sales is positively related to the relative skilled-labor abundance of the parent, and negatively related to market size, the host-country investment cost index, and the host-country trade-cost index. The findings on trade and investment costs may be due to a substitution phenomenon. If the investment is undertaken to serve the local market, firms will bear the trade and investment costs. If the investment is made to serve the market in the parent or third countries, high local trade and investment costs will induce the firm to look elsewhere. 


\section{The Knowledge-Capital Model}

In this section, we outline what we refer to as the "knowledge-capital model" of the multinational enterprise. A formal algebraic development is presented in Markusen (1997), and many of its testable implications are analyzed in CMM (1998).

Assume a two-good, two-factor, two-country world. Refer to the factors as skilled (S) and unskilled (L) labor. Good Y is produced with constant returns to scale by a competitive industry and is unskilled-labor intensive. The countries are referred to as $\mathrm{h}$ (home) and $\mathrm{f}$ (foreign).

Good $\mathrm{X}$ is produced with increasing returns by imperfectly competitive, Cournot firms. Production of X requires a firm-level fixed cost, "headquarters' services", such as R\&D, management, finance, accounting, marketing and so forth. An X firm may then have one or two plants, and a plant and headquarters may be geographically separated. Headquarters' services are a joint input across plants, creating firm-level scale economies, also referred to in the literature as multi-plant economies of scale. The idea is that headquarters' services are often knowledge-based and can be provided to additional production facilities at low or zero marginal cost (e.g., blueprints). We also assume plantlevel fixed costs (scale economies).

Assumptions about the factor intensities of fixed costs are crucial to the story. We assume that headquarters' services use skilled labor exclusively. Plant level fixed costs are a combination of skilled and unskilled labor. Final production occurs with constant costs and requires only unskilled labor. Transport costs between markets use unskilled labor. Finally, we assume that plant production, including both fixed costs and marginal costs, is more skilled-labor intensive than $\mathrm{Y}$ production, the composite of the rest of the economy. This is not particularly important to any of the results in this paper, but is important in generating certain results concerning the factor-price effects 
of investment liberalization (Markusen, 1997). In summary then, the ranking of activities from most skilled-labor intensive to least skilled-labor intensive is as follows:

[headquarters only] $>$ [integrated $\mathrm{X}]>[$ plant only $]>[\mathrm{Y}]$

This completes the description of the model, and allows us to specify more precisely what is meant by the knowledge-capital approach. There are three defining assumptions.

(A) Transportability or fragmentation: the services of knowledge-based assets may be fragmented from production and are easily supplied to geographically separate production facilities.

(B) Skilled-labor intensity: knowledge-based assets are skilled-labor intensive relative to final production.

(C) Jointness: the services of knowledge-based assets are (at least partially) joint ("public") inputs into geographically separate production facilities.

The first two properties gives rise to "vertical" multinationals that locate their single plant and headquarters in different countries depending on factor prices and market sizes. The third property gives rise to "horizontal" multinationals that have plants producing the final goods in multiple countries.

More formally, several types of firms may be active in equilibrium in a free-entry Cournot equilibrium for the model we have just outlined. "National firms" refer to single-plant firms with their headquarters and plant in the same country. "Horizontal multinationals" refer to two-plant firms with their headquarters in one country or the other. "Vertical multinationals" refer to single-plant firms with their headquarters and plant in different countries.

Here we just outline the results that emerge from this model with respect to what types of 
firms are active in equilibrium as a function of country characteristics, such as differences in size, relative endowments, and the level of trade costs and total world demand. The interested reader is referred to Markusen (1997) for a fuller development.

Horizontal multinationals tend to arise when the two countries are similar in size, similar in relative endowments, total demand is high, and trade costs are moderate to high. In order to understand the importance of similarity in size, it is perhaps easiest to note that single-plant firms (national or vertical) have an inherent advantage when the countries are of very different size: put a single plant in the large country, avoiding costly capacity in the small market. Growth in total demand will induce shifts (in some regions of parameter space) from single-plant production, serving the other market by high-marginal-cost exports, to high-fixed-cost branch-plant production.

Vertical multinationals are favored over national firms and horizontal multinationals when the countries have very different relative endowments and especially when the skilled-labor-abundant country is also small. Differences in factor prices encourage fragmentation of activities, with the headquarters in the skilled-labor-abundant country and differences in size encourage placing the plant in the large country. These two motives reinforce one another when the skilled-labor-abundant country is also small.

These results are interesting, but not very useful to take to the data. We do not have good data on the types of firms existing and these pure types are greatly blurred in reality in any case. However, the model can be used to generate results on the sales of affiliates of country i firms in country $\mathrm{j}$. This "reduced form" gives us direct predictions on observable data, fully endogenizing the types of firms active, trade flows, and so forth, without requiring us to identify those items in the data. 
Figures 1-4 present results from simulations using the model from Markusen (1997) and CMM (1998). These diagrams are world Edgeworth boxes, with unskilled labor on the "x" axis and skilled labor on the "y" axis. The origin for country $i$ is at the southwest (SW) corner and the origin for country $\mathrm{j}$ is at the northeast (NE) corner. For points on the SW-NE diagonal, the countries have the same relative endowments but differ in size. Note for reference later that movements within these Edgeworth boxes are "compensated" experiments, in that total world factor endowments are constant (and therefore world GDP is approximately constant). These diagrams are most useful for developing intuition about two-way data in which we observe production and sales by affiliates of country i firms in country $\mathrm{j}$ and vice versa. Thus in any pair ( $\mathrm{i}$ to $\mathrm{j}$ and $\mathrm{j}$ to $\mathrm{i}$ ) of observations total GDP and factor endowments are held constant.

Affiliate sales are graphed on the vertical axis of Figure 1. Affiliate sales appear as a saddle, with an inverted u-shaped curve along the SW-NE diagonal. As noted earlier, horizontal multinationals dominate production when the countries are identical, while national firms located in the larger country dominate when the countries are very different in size. In the center of the box, exactly half of world production is affiliate sales, while the other half is the output of the horizontal multinationals' domestic plants.

The highest level of affiliate sales occurs in the NW and SE areas of the Edgeworth box in Figure 1, where one country is both small and skilled-labor abundant. ${ }^{1}$ In this case, most firms are vertical multinationals headquartered in the small, skilled-labor-abundant country, and so most plants are located in the larger, skilled-labor-scarce country. Output of these plants is classified as "affiliate production" of course, so most (in the limit all) world X production is affiliate sales.

Figures 2, 3, and 4 show simulation results for affiliate sales in just one direction: affiliates of 
country $i$ firms producing in country $j$. Figure 2 shows the local sales in country $j$ of affiliates of country i firms. There is again an inverted $u$-shaped relationship along the SW-NE diagonal. But the highest levels occur when country $i$ is both small and skilled-labor abundant for the reasons just noted.

Figure 3 shows the export sales of affiliates back to the parent country i. This diagram is a "mountain", reaching a maximum when country $\mathrm{i}$ is small and skilled-labor abundant, but not too small and not too skilled-labor scarce. The not-too-small requirement is obvious, because little output is exported back to a very small country. The not-too-skilled-labor-abundant requirement is less obvious, and it has to do with the assumption that some host-country skilled labor is required in plant-level fixed costs. As country $\mathrm{j}$ becomes too skilled-labor scarce, production there becomes very expensive and national firms in country $\mathrm{j}$ substitute for vertical firms headquartered in $\mathrm{i}$ and producing in $\mathrm{j}$.

There are clear differences between Figures 2 and 3. Most notably, only local sales occur if the countries are very similar, or if country $i$ is very small and very skilled-labor abundant. Yet there are some similarities that make it difficult to propose sharply different hypotheses regarding how these two classes of affiliate sales should be related to country characteristics.

Figure 4 clarifies this ambiguity a bit by displaying the ratio of affiliate exports back to the parent to local affiliate sales in the host country. This graph suggest that this ratio is most closely related to the skilled-labor abundance of the parent in relation to the host country. Relative size differences play some role, but the ratio clearly is not higher when the parent country $i$ is both small and skilled-labor abundant. ${ }^{2}$

These simulation results suggest a number of independent variables that should be used to explain the three dependent variables: local sales by affiliates of country i firms in country $j$ (Figure 
2), export sales by the same affiliates (Figure 3), and the ratio of these two variables (Figure 4). Refer to these variables as RSALESL, RSALESE, and RATIOEL ( $\mathrm{R}$ for "real" in the first two). We now list the right-hand-side variables, adding a discussion of the hypothesized signs and magnitudes using Figures 1-4 and other more obvious intuition. Again, note that these hypotheses are most appropriate to two-way "compensated" observations as noted earlier. We shall return to this point below.

SUMGDP denotes the sum of two countries' real GDPs. This should have a positive coefficient in explaining RSALESL and RSALESE. However, the effect should be stronger on RSALESL. The reason is that growth will, at various points in parameter space, lead to a switch from high marginal-cost single-plant firms to high-fixed-cost multi-plant firms, increasing local sales more than in proportion to growth in incomes. Accordingly, we hypothesize that RATIOEL should be negatively related to SUMGDP.

GDPDIFF is the difference between the two countries' real GDP levels and GDPDIFSQ is the squared difference. GDPDIFSQ should be negatively related to all three dependent variables, as suggested by Figures 2-4. Moving along various loci parallel to the SW-NE diagonal, all three dependent variables are higher near the center than at the extremes, although the maximum point is generally not exactly where the two countries are the same size.

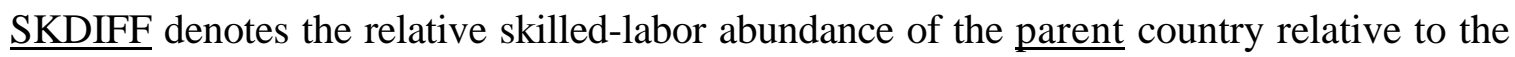
host; formally, it is the share of the labor force that is skilled in country $i$ (parent or source) minus the same share in country $\mathrm{j}$ (host). SKDIFF should be positively related to both RSALESL and RSALESE. However, it is likely to have a stronger impact on RSALESE than on RSALESL from eye-balling Figures 2 and 3. Relative endowments and factor-price differences are the primary determinants of export sales, whereas local sales are influenced heavily by country sizes as well. 
Accordingly, we hypothesize that SKDIFF will have a positive sign in the RATIOEL regression as suggested by Figure 4 .

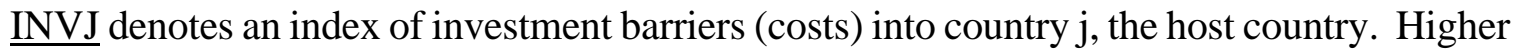
numbers indicate higher investment costs. This is hypothesized to be negatively related to both RSALESL and RSALESE. However, investments to serve the local market may be less sensitive to these costs than are investments to serve export markets because alternative locations may be selected for the latter, thus we hypothesize that the magnitude of the coefficient in the RSALESL equation should be less than that in the RSALESE equation, and therefore that the sign on INVJ should be negative in the RATIOEL equation as well.

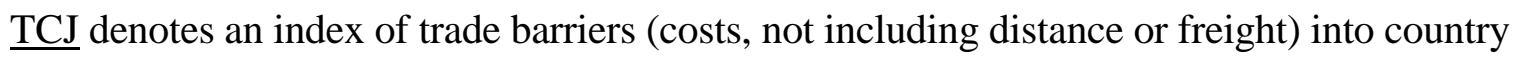
j. Higher numbers indicate higher barriers or costs. Such barriers should encourage investments to serve the local market, so the hypothesized sign is positive in the RSALESL equation. The effect should be noticeably less in the RSALESE equation and may be negative, insofar as trade costs raise the costs of imported intermediate inputs. The sign of the coefficient in the RATIOEL equation should thus be negative.

$\underline{\mathrm{TCI}}$ is a similar measure of trade barriers back into the parent country. This has little effect on production for local sales in country $\mathrm{j}$, but is expected to have a negative effect on production for export, insofar as much of that may be going back to the home country. This variable should thus have a negative sign in the RATIOEL equation.

SKDIFF*GDPDIFF is an interactive term. Referring to Figures 2-3, the effect of an increase in SKDIFF should be larger when the parent is smaller (GDPDIFF $<0$ ), and the effect of an increase in GDPI (parent GDP) should be smaller when the parent country i is skilled-labor abundant (SKDIFF 
$>0$ ). Both effects imply that the sign of the coefficient on the interactive term should be negative in the RSALESL and RSALESE regressions. Figure 4 however does not suggest a very sharp hypothesis as to whether it should be positive or negative in the RATIOEL equation. Therefore, we are agnostic about the sign in the RATIOEL equation.

DIST will denote a distance measure between pairs of counties. Theory does not offer us much of a prediction about distance. It may lead to a substitution to producing abroad instead of exporting to a distant country. However, distance raises the transactions costs of investments as well as those of exports. It is possible that distance might affect production for export more negatively than production for local sale (which might actually be encouraged), but we are generally agnostic insofar as we do not understand the transactions costs of investing at a long distance.

In addition to examining these hypotheses on two-way data (inward and outward affiliate sales data for the US), we examine them on US outward data only. The advantage of the latter is that it breaks down affiliate export sales into sales back to the parent country and sales to third countries. Sales back to the US parent may be closely identified with vertical investments such as foreign assembly plants. We should note, however, that the intuition generated by figures 1-4 may not always be appropriate, insofar as these diagrams are "compensated" experiments holding the two-country total factor endowment constant. Thus an increase in SKDIFF is an increase in the US skilled-labor abundance and a fall in the host-country skilled-labor abundance in the simulations. For the US outward data, an increase in SKDIFF is a fall in the host-country skilled-labor abundance holding the US endowment constant. Similar comments apply to GDPDIFF and in the outward regressions we will use GDPJ since it is only the latter variable that changes.

A problematic issue with the outward-only data arises from the fact that the US (the parent) 
is always far bigger than the host, although not always skilled-labor abundant relative to the host. This restricts observations to an area in the NE section of the Edgeworth boxes in Figures 2-4, which is a considerable difficulty given the non-linearity and non-monotonicity of the theoretical predictions over the parameter space of the Edgeworth box. For example, note that increases in SKDIFF could lead to a fall in outward US investment in this region (foreign plants are replaced by US national firms serving the host by exports). Thus we should expect some differences in the US-outward-only results versus the two-way results due to the fact that they are somewhat different experiments and because we are constrained to a sub-region of parameter space in the outward-only data. Further comment is postponed until we view the results. 


\section{Data Sources and Variable Construction}

The data form a panel of cross-country observations over the period 1986-94. We take real sales volume of non-bank manufacturing affiliates in each country to indicate production activity. The U.S. Department of Commerce provides annual data on sales of foreign affiliates of American parent firms and on sales of U.S. affiliates of foreign parent firms. Thus, for each year the United States serves as both the headquarters country for its firms producing abroad and the affiliate country for foreign firms producing there. There are 36 countries in addition to the United States for which we have at least one year of complete data. Annual sales values abroad are converted into millions of 1990 U.S. dollars using an exchange-rate adjusted local wholesale price index, with exchange rates and price indexes taken from the International Financial Statistics of the International Monetary Fund.

As noted above, the "inward" data (U.S. affiliates of foreign parents) only list total exports of the affiliates to all countries. The "outward" data (foreign affiliates of U.S. parents) break down exports of those affiliates into exports back to the United States and exports to third countries. The latter series is particularly valuable, but constrains the analysis to a sub-area of the Edgeworth box in which the parent country (United States) is always very large relative to the host as noted above. The inward-outward (two-way) data are thus in some ways much for examining the theory, but suffer from a clear third-country problem, whereas the theory is developed in a two-country context. Thus, we examine two cases, each of which has a drawback: the inward-outward data using total affiliate export sales to all countries and outward-only data in which exports can be distinguished between exports back to the parent and exports to third countries.

Real gross domestic product is measured in billions of 1990 U.S. dollars for each country. 
For this purpose, annual real GDP figures in local currencies were converted into dollars using the market exchange rate. These data are also from the IFS.

Skilled labor abundance is defined as the sum of occupational categories 0/1 (professional, technical, and kindred workers) and 2 (administrative workers) in employment in each country, divided by total employment. These figures are compiled from annual surveys reported in the Yearbook of Labor Statistics published by the International Labor Organization. In cases where some annual figures were missing, the skilled-labor ratios were taken to equal the period averages for each country. The variable SKDIFF is then simply the difference between the relative skill endowment of the parent country and that of the affiliate country.

The cost of investing in the affiliate country is a simple average of several indexes of impediments to investment throughout the period, reported in the World Competitiveness Report of the World Economic Forum. The indexes include restrictions on ability to acquire control in a domestic company, limitations on the ability to employ foreign skilled labor, restraints on negotiating joint ventures, strict controls on hiring and firing practices, market dominance by a small number of enterprises, an absence of fair administration of justice, difficulties in acquiring local bank credit, restrictions on access to local and foreign capital markets, and inadequate protection of intellectual property. These indexes are computed on a scale from 0 to 100 , with a higher number indicating higher investment costs.

A trade cost index is taken from the same source and is defined as a measure of national protectionism, or efforts to prevent importation of competitive products. It also runs from 0 to 100 , with 100 being the highest trade costs. All of these indexes are based on extensive surveys of multinational enterprises. 
We also incorporate a measure of distance, which is simply the number of kilometers of each country's capital city from Washington, DC. It is unclear whether this variable captures trade costs or investment costs, since both should rise with distance. 


\section{4. $\quad \underline{\text { Results }}$}

Tables 1-3 show results for regression equations on the full inward-outward data set. Table 1 gives results for dependent variable RSALESL (local sales in country $\mathrm{j}$ of affiliates of country $\mathrm{i}$ firms). Signs are as predicted for direct effects although the two variables involving SKDIFF are not statistically significant. Country size, investment costs, and trade costs into the host country market have strong explanatory power. Trade costs back into the parent country (TCI) have little explanatory power and theory does not hypothesize that it should.

Table 2 gives results for dependent variable RSALESE (export sales to all countries by affiliates of country i firms in country j). Signs are as hypothesized except for TCI, which should be negative, at least for exports going back to the home countries (these cannot be broken out in the data as noted above). The two terms involving SKDIFF are both larger in magnitude (economic significance) than in the RSALESL regression, and highly statistically significant. The magnitude of the SUMGDP coefficient on the other hand is much smaller in the RSALESE regression. These results suggest that market size is a more important determinant of production for local sales while differences in relative endowments is a more important determinant of production for export.

These comparisons can be misleading, however, due to differences in the size of the dependent variables (local sales are larger than export sales in most observations). Table 3 therefore uses the ratio of export sales to local sales. Results confirm that market size is more important for local sales (coefficient on SUMGDP is negative) and that skill differences are more important for export sales (coefficient on SKDIFF is positive), thus the proportion of export sales increases as host country $\mathrm{j}$ becomes more unskilled-labor abundant (skilled-labor scarce).

The coefficients on the INVCJ and TCJ variables in the ratio equation of Tables 3 are 
negative. This conforms to our intuition about substitutability. Production for local sale, by definition, cannot move to a third country, and thus local sales may be relatively insensitive to these costs. Production for export sale may be more sensitive to investment and trade costs because the firm can choose an alternative location to serve a broader market, as suggested by the negative signs in the ratio equation. TCI is positive in this regression which is consistent with results in Tables 1 and 2. This outcome is not consistent with our intuition but note that the significance level is low. Higher parent country trade costs should discourage foreign production for export back to the parent, but should not affect production for local sale.

Tables 4-8 present results on the US-outward-only sample, allowing a breakdown of production for export sale into sales back to the United States (RSALESUS in Table 5) and sales to third countries (RSALESF in Table 6). The most dramatic change in these results relative to Tables $1-3$ is the reversal in the signs of SKDIFF and GDPDIFF*SKDIFF. This suggests that US outward investment is attracted to more skilled-labor abundant countries both for local production and production for export with strong statistical significance. The latter result is particularly at odds with the two-way results.

There are two possible explanation, other than just concluding that inward and outward investments follow different models. First, there is the "compensated" versus "uncompensated" issue that we mentioned earlier. In the US-outward-only data, an increase in SKDIFF holds US skilledlabor-abundance constant, effectively lowering "world" skilled-labor abundance. This is a somewhat different experiment than that in the two-way data, which includes both such uncompensated observations across different countries, and also a great many "compensated" observation pairs comparing i-to-j and $j$-to-i affiliate production. The response of affiliate production to an increase 
in host-country skilled-labor abundance (decrease in SKDIFF) should be more positive or less negative than if this change is accompanied by a fall in the parent country skilled-labor abundance and that is what the results are telling us.

The second possible explanation relates to the fact that the parent country (the United States) is always much larger than the host in the US-outward data. How this might affect the results is shown most clearly in Figure 2. When country $\mathrm{i}$ is quite large relative to country j, a (compensated) increase in SKDIFF may produce a fall in RSALESL: heading toward the north edge of the box, we go over the "hump" and RSALESL start to fall. What is happening in the theory model is that host country $\mathrm{j}$ is becoming sufficiently skilled-labor scarce that branch plants there are closed and production is concentrated in national firms headquartered in country $i$. This implies a negative sign on SKDIFF which is the result we are getting in Tables 4-6. This finding is in fact consistent with results in Zhang and Markusen (1999), which show that the smallest, poorest (skilled-labor scarce) countries receive a far smaller share of world direct investment than their share of income. The result and associated theory also points out the importance of knowing which part of the box is being examined and of adding more investing countries as is done in the two-way sample.

Table 7 shows results for the ratio of affiliate export sales back to the United States to affiliate sales to the local market, and Table 8 shows results for the ratio of affiliate sales to third markets to affiliate sales to the local market. Results on market size confirm those in Table 3, that a larger market shifts a proportion of sales from exports to local sales. The findings also confirm the results on INVCJ and TCJ (TCI was dropped because country $\mathrm{i}$ is always the United States). The results on SKDIFF and GDPDIFF*SKDIFF are reversed; however, these point estimates have extremely low statistical significance in Table 7, while the positive sign on SKDIFF in Table 3 is highly significant. 
Both coefficients are statistically significant in Table 8 . Thus the results suggest that US outward investment is not attracted to low-skilled countries, even investment for production for export back to the United States (Table 5).

Results on market size and relative endowments must be interpreted carefully, however, since GDP appears in three terms and relative endowments in two terms. Let us write the first four terms of the regression equations as:

$$
\beta_{1} S U M G P D+\beta_{2} \text { GDPDIFSQ }+\beta_{3} \text { SKDIFF }+\beta_{4} \text { GDPDIFF } * \text { SKDIFF }
$$

The derivatives of this equation with respect to host-country variables GDPJ and SKLJ are then as follows (an increase in GDPJ is a negative change in GDPDIFF, and an increase in SKLJ is a negative change in SKDIFF).

$$
\frac{\partial R S A L E S}{\partial G D P J}=\beta_{1}-2 \beta_{2} \text { GDPDIFF }-\beta_{4} S K D I F F
$$

$$
\frac{\partial R S A L E S}{\partial S K L J}=-\beta_{3}-\beta_{4} G D P D I F F
$$

Table 9 computes values of these derivatives at the mean values of SKDIFF and GDPDIFF for the two samples. Table 9 gives the absolute change in sales by country $\mathrm{i}$ affiliates in $\mathrm{j}$ in response to a growth in country j's income and to an increase in country j's skilled-labor abundance (decrease in its unskilled-labor abundance). Effects of increases in country j's investment and trade-cost indices are also listed. The top panel gives results for the inward-outward estimation while the lower panel 
gives estimates for the US outward estimation only. Below the level estimates, an elasticity figure is computed. We do not compute elasticities with respect to INVCJ and TCJ, since these are "qualitative" indices.

According to results in the top panel of Table 9, local sales are elastic with respect to hostcountry income with an elasticity of $\epsilon=1.6$. Export sales are less elastic, at $\epsilon=1.1$. Local sales are very insensitive to the skilled-labor ratio in the host country, while export sales have an elasticity with respect to the skilled-labor ratio of $\epsilon=-.7$. Production for export sales is attracted to less skilledlabor abundant (more skilled-labor scarce) countries. Comparing local sales versus export sales, the former respond more to income and export sales respond more to skilled-labor scarcity as suggested by the regression results discussed earlier.

The pattern for the US-outward-only data (lower panel of Table 9) is qualitatively similar to the top panel but quantitatively different. Production for local sale has an elasticity with respect to local market size of about 1.0, while the elasticities of exports back to the US and to third countries are 0.2 and 1.0, respectively. A weighted average of these two elasticities $(\epsilon \mathrm{w})$ yields a figure of 0.68. Thus the elasticity of exports with respect to host-country size is less than that for local sales by an amount similar to the two-way estimates. The elasticity of local sales with respect to the hostcountry skilled-labor ratio is about 0.6 , while the average of the two export elasticities is 0.06 . Production for export back to the US or to third countries is insensitive to the host-country skilledlabor ratio, at least at the mean of GDPDIFF. Again, the pattern is qualitatively similar to that for the two-way estimate in that the export elasticity with respect to local skilled labor is smaller than that for local sales (i.e., less positive or more negative).

Overall, the results in Table 9, taking into account interactive effects, clearly confirm that 
production for local sales is more sensitive to local market size than is production for export. Production for local sales has an elasticity with respect to the host-country skilled-labor ratio that is larger than the elasticity for production for export. Production shifts relatively in favor of local sales when the host is more skilled-labor abundant and relatively in favor of exports when the host is skilled-labor scarce.

There is an interesting quantitative difference between the two-way and US-outward estimates of the elasticities with respect to the host-country skilled-labor ratio (subject again to the caveats that these are point estimates, evaluated at the mean of GDPDIFF in each sample, and the means differ in the two samples). While production for export is attracted by host-country unskilled-labor abundance in the two-way sample, there is virtually no effect in the US-outward sample. We might infer from this that production by US affiliates for export, including that back to the United States, is not primarily attracted to low-skilled countries, contrary to a popular impression of multinationals exporting jobs to low-wage countries. While this may occur in arm's-length outsourcing (e.g., subcontracting), our results suggest that it is not primarily multinationals that are responsible for such a phenomenon if it indeed exists. As we noted above, this is consistent with the theoretical assumption that branch-plant production is skilled-labor intensive relative to the rest of the host economy. Past a certain level of skilled-labor scarcity in the host economy, inward direct investment begins to fall as that country becomes increasingly skilled-labor scarce (Zhang and Markusen, 1999). 


\section{Summary and Conclusions}

Robert Lipsey's work over many years has given us a rich empirical literature that relates the behavior of multinational firms to industry and country characteristics. Theoretical work that endogenizes multinational firms into general-equilibrium trade models has developed somewhat more recently, and offers predictions about the relationship between affiliate production and parent-country and host-country characteristics. In particular, the knowledge-capital approach to the multinational enterprise identifies motives for both horizontal and vertical multinational activity and predicts how affiliate activity should be related to variables such as country sizes and relative-endowment differences.

This paper draws implications from the theory as to how production for local sales versus production for export sales relates to country characteristics and then subjects these hypotheses to empirical estimation. Results fit well with the theory in terms of economic and statistical significance. Local (host-country) market size is more important for production for local sales than for production for export sales. Host-country skilled-labor scarcity is important for export production relative to production for local sales. Investment and trade cost barriers in the host country affect production for export more negatively than production for local sales.

Some quantitative difference was found in the two-way (inward and outward) sample versus the US-outward only sample with respect to host-country skilled labor abundance or scarcity. In the US-outward only sample, host-country skilled-labor scarcity (unskilled-labor abundance) had little effect on US affiliate production for export sale, whether back to the United States or to third countries. This suggests that US outward investment is not primarily drawn to unskilled-laborabundant countries, contrary to a common fear that "outsourcing" by multinationals is resulting in a 
loss of US unskilled jobs. (Firms could of course be outsourcing to unaffiliated sub-contractors.) In the two-way sample, production for exports is drawn to unskilled-labor-abundant countries. However, the results are qualitatively similar in the two samples insofar as unskilled-labor-abundance in the host is relatively more important for export sales. 


\section{REFERENCES}

Bhagwati, Jagdish N. and Richard A. Brecher (1980), "National Welfare in an Open Economy in the presence of Foreign-Owned Factors of Production", Journal of International Economics 10, 103-15.

Blomstrom, Magnus, Irving B. Kravis, and Robert E. Lipsey (1988), "Multinational Firms and Manufacturing Exports from Developing Countries", NBER working paper 2493.

Blomstrom, Magnus and Robert E. Lipsey (1989), "The Export Performance of US and Swedish Multinationals", Review of Income and Wealth 35, 245-64.

(1993), "The Competitiveness of Countries and Their Multinational Firms", in Eden, Lorraine and Evan H. Potter (editors), Multinationals in the Global Political Economy, New York: St. Martin's Press, 129-41.

Blomstrom, Magnus, Robert E. Lipsey, and Ksenia Kulchycky (1998), "US and Swedish Direct Investment and Exports", in Baldwin, Robert E. (editor), Trade Policy Issues and Empirical Analysis, Chicago and London: University of Chicago Press, 259-97.

Blomstrom, Magnus Robert E. Lipsey, and Lennart Ohlsson (1990), "What do Rich Countries Trade with One Another? R\&D and the Composition of US and Swedish Trade", Banca Nazionale del Lavoro - Quarterly Review 173, 215-35.

Blonigen, Bruce (1997), "Firm-Specific Assets and the Link Between Exchange Rates and Foreign Direct Investment", American Economic Review 87, 447-466.

(1998), "In Search of Substitution between Foreign Production and Exports", University of Oregon working paper.

Brainard, S. Lael (1993a), "A Simple Theory of Multinational Corporations and Trade with a Tradeoff between Proximity and Concentration", NBER Working Paper No. 4269.

(1993b), "An Empirical Assessment of the Factor Proportions Explanation of Multinationals Sales", NBER Working Paper No. 4580.

(1996), "An Empirical Assessment of the Proximity-Concentration Tradeoff between Multinational Sales and Trade", American Economic Review 87, 520-544.

Brecher, Richard A. and Carlos F. Diaz-Alejandro (1977), "Tariffs, Foreign Capital and Immiserizing Growth", Journal of International Economics 7, 317-322.

Carr, David, James R. Markusen and Keith Maskus (1998), "Estimating the Knowledge-Capital 
Model of the Multinational Enterprise", NBER working paper 6773.

Dick, Andrew R. (1993), "Strategic Trade Policy and Welfare: The Empirical Consequences of Foreign Ownership", Journal of International Economics 35, 227-249.

Ekholm, Karolina (1995), Multinational Production and Trade in Technological Knowledge, Lund Economic Studies, number 58.

(1997), "Factor Endowments and the Pattern of Affiliate Production by Multinational Enterprises", CREDIT working paper no. 97/19, University of Nottingham.

(1998a), "Headquarter Services and Revealed Factor Abundance", Review of International Economics 6, 545-553.

(1998b), "Proximity Advantages, Scale Economies, and the Location of Production", in Braunerhjelm, Pontus and Karolina Ekholm (editors), The Geography of Multinational Firms. Boston: Kluwer Academic Publishers, 59-76.

Ethier, Wilfred and Lars E.O. Svensson (1986), "Theorems of International Trade with Factor Mobility", Journal of International Economics 20, 21-42.

Helpman, Elhanan, (1984) "A Simple Theory of Trade with Multinational Corporations", $\underline{\text { Journal of }}$ Political Economy, 92, 451-471.

(1985)"Multinational Corporations and Trade Structure", Review of Economic Studies $52,443-458$.

Horstmann, Ignatius J. and James R. Markusen (1987), "Strategic Investments and the Development of Multinationals," International Economic Review 28, 109-121.

(1992), "Endogenous Market Structures in International Trade," Journal of International Economics 32, 109-129.

Kemp, Murray C. (1969), The Pure Theory of International Trade and Investment, New York: Prentice Hall.

Kravis, Irving B. and Robert E. Lipsey (1982), "The Location of Overseas Production and Production for Export by US Multinational Firms", Journal of International Economics 12, 210-23.

(1988), "The Effect of Multinational Firm's Foreign Operations on Their Domestic Employment", NBER working paper 2760. 
(1992), "Sources of Competitiveness of the United States and of its Multinational Firms", Review of Economics and Statistics 74, 193-201.

Linder, Staffan Burenstam (1961), An Essay on Trade and Transformation, Uppsala: Almqvist and Wiksells.

Lipsey, Robert E. (1988), "Changing Patterns of International Investment in and by the United States", in Martin Feldstein (editor), The United States and the World Economy, Chicago and London: University of Chicago Press, 475-545.

(1989), "The Internationalization of Production", NBER working paper 2923.

(1993), "Foreign Direct Investment in the United States: Changes over Three Decades", in Froot, Kenneth A. (editor), Foreign Direct Investment, Chicago and London: University of Chicago Press, 113-70.

(1995), "Outward Direct Investment and the US Economy", in Feldstein, Martin, James R. Hines, and Glenn Hubbard (editors), The Effects of Taxation on Multinational Corporations, Chicago and London: University of Chicago Press, 7-33.

Lipsey, Robert E., Magnus Blomstrom and Eric Ramstetter (1995), "Internationalized Production in World Output", NBER working paper 5385.

Lipsey, Robert E. and Irving B. Kravis (1987), The Competitiveness and Comparative Advantage of US Multinationals 1957-1984", Banca Nazionale del Lavoro - Quarterly Review 161, 147-65.

Lipsey, Robert E. and Merle Yahr Weiss (1981), "Foreign Production and Exports in Manufacturing Industries", Review of Economics and Statistics 63, 210-23.

(1984), "Foreign Production and Exports of Individual Firms", Review of Economics and Statistics 66, 304-308.

Markusen, James R. (1983), "Factor Movements and Commodity Trade as Complements," Journal of International Economics 13, 341-356.

(1984), "Multinationals, Multi-Plant Economies, and the Gains from Trade", Journal of International Economics 16, 205-226.

(1995), "The Boundaries of Multinational Firms and the Theory of International Trade", Journal of Economic Perspectives 9, 169-189.

(1997), "Trade versus Investment Liberalization", NBER working paper 6231. 
Markusen, James R. and Lars E.O. Svensson (1985), "Trade in Goods and Factors with International Differences in Technology," International Economic Review 26, 175-192.

Markusen, James R. and Anthony J. Venables (1998), "Multinational Firms and the New Trade Theory", Journal of International Economics 46, 183-203.

Melvin, James R. (1969), "Increasing Returns to Scale as a Determinant of Trade", Canadian Journal of Economics 3, 389-402.

Mundell, Robert (1957), "International Trade and Factor Mobility", American Economic Review 47, 321-335.

Neary, J. Peter (1995), "Factor Mobility and International Trade", Canadian Journal of Economics 28, S4-S23.

Smith, Pamela J. (1998), "Patent Rights and Bilateral Exchange: A Cross-Country Analysis of US Exports, FDI, and Licensing", University of Minnesota working paper.

Swenson, Debra (1998), "The Tradeoff between Trade and Foreign Investment", University of California, Davis, working paper.

Wong, Kar-Yui (1986), "Are International Trade and Factor Mobility Substitutes?", $\underline{\text { Journal of }}$ International Economics 20, 25-44.

Zhang, Kevin Honglin and James R. Markusen (1999), "Vertical Multinationals and Host-Country Characteristics", Journal of Development Economics, forthcoming. 


\section{ENDNOTES}

1. The locus of point in which countries $i$ and $j$ have equal incomes is much steeper than the NE-SE diagonal of the Edgeworth boxes in Figures 1-4. It runs between columns 8 ("north"

edge) and column 12 ("south" edge). So, for example, country $i$ is smaller than $j$ to the left of this locus.

2. Recall that country $i$ is smaller than country $j$ at all points left of a line running from approximately column 8 on the north side of the box to column 12 on the south side. 
Table 1: Results for Panel estimation, inward and outward data

Dependent variable:

Total observations

R-Squared

Adjusted R-Squared
RSALESL (weighted least squares) 381

0.728

0.722

Variable

$\begin{array}{rrrr}\text { Parameter } & \text { Sign as } & \text { T for HO: } & \text { Prob }>|\mathrm{T}| \\ \text { Estimate } & \text { Predicted? } & \text { Parm }=0 & \end{array}$

SUMGDP

GDPDIFSQ

10.2937

$-0.0009$

Yes

9.108

0.0001

10531

Yes

$-7.163$

0.0001

SKDIFF

GDPDIFF*SKDIFF

$-2.6932$

Yes

0.877

0.3813

$-1.114$

0.2658

INVCJ

$-633.3970$

366.5574

$-22.0996$

Yes

Yes

$-7.119$

0.0001

TCJ

Yes

6.142

0.0001

$\mathrm{TCl}$

$-1.5326$

469.22

$-0.195$

0.8451

DIST

INTERCEPT

$-9.293$

0.046

0.0001

0.9631

Table 2: Results for Panel estimation, inward and outward data

Dependent variable:

Total observations

R-Squared

Adjusted R-Squared

Variable

SUMGDP

GDPDIFSQ

SKDIFF

GDPDIFF*SKDIFF

INVCJ

TCJ

$\mathrm{TCl}$

DIST

INTERCEPT
RSALESE (weighted least squares)

381

0.486

0.473
Parameter

Estimate

$$
\begin{array}{r}
2.9274 \\
-0.0003 \\
42961 \\
-6.9520
\end{array}
$$

$-277.2284$

52.1164

65.6274

$-0.6398$

7501.94
Sign as

Predicted?

Yes

Yes

Yes

Yes

Yes

?

NO

?
T for $\mathrm{HO}: \quad$ Prob $>|\mathrm{T}|$ Parm $=0$

3.971

0.0001

0.0005

0.0001

0.0001

0.0001

0.1836

0.3729

$-4.758$

1.332

0.892

0.3729

$-5.927$

0.0001

1.127

0.2604 
Table 3: Results for Panel estimation, inward and outward data

Dependent variable:

Total observations

R-Squared

Adjusted R-Squared

Variable

SUMGDP

GDPDIFSQ

SKDIFF

GDPDIFF*SKDIFF

INVCJ

TCJ

$\mathrm{TCl}$

DIST

INTERCEPT
RATIOEL (weighted least squares)

371

0.335

0.319

$\begin{array}{rrrr}\begin{array}{r}\text { Parameter } \\ \text { Estimate }\end{array} & \begin{array}{r}\text { Sign as } \\ \text { Predicted? }\end{array} & \begin{array}{r}\text { T for HO: } \\ \text { Parm }=0\end{array} & \text { Prob }>|\mathrm{T}| \\ & & & \\ -0.000671 & \text { Yes } & -4.327 & 0.0001 \\ -1.92 \mathrm{E}-08 & \text { Yes } & -1.209 & 0.2273 \\ 3.175373 & \text { Yes } & 3.121 & 0.0019 \\ -0.000043 & ? & -0.173 & 0.8630 \\ & & & \\ -0.043374 & \text { Yes } & -3.491 & 0.0005 \\ -0.010975 & \text { Yes } & -1.261 & 0.2082 \\ 0.014789 & \text { No } & 1.094 & 0.2749 \\ 0.000055 & & & \\ 6.100586 & ? & 2.446 & 0.0149 \\ & & 4.222 & 0.0001\end{array}$


Table 4: Results for Panel estimation, US outward only

Dependent variable: RSALESL (weighted least squares)

Total observations

R-Squared

274

Adjusted R-Squared

0.773

0.766

Variable

$\begin{array}{rrrr}\text { Parameter } & \text { Sign as } & \text { T for HO: } & \text { Prob }>|\mathrm{T}| \\ \text { Estimate } & \text { Predicted? } & \text { Parm }=0 & \end{array}$

GDPJ

GDPDIFSQ

20.8423

Yes

10.362

0.0001

$-0.0018$

Yes

$-8.120$

0.0001

$-948636$

SKDIFF

174.5818

?

$-11.980$

0.0001

GDPDIFF*'SKDIFF

?

11.905

0.0001

INVCJ

$-517.8056$

Yes

$-6.546$

0.0001

TCJ

314.8092

Yes

5.943

0.0001

DIST

$-1.2044$

$?$

$-7.810$

0.0001

INTERCEPT

73798.00

9.863

0.0001

Table 5: Results for Panel estimation, US outward only

Dependent variable:

Total observations

R-Squared

Adjusted R-Squared

Variable

GDPJ

GDPDIFSQ

SKDIFF

GDPDIFF*SKDIFF

INVCJ

TCJ

DIST

INTERCEPT
RSALESUS (weighted least squares)

$$
244
$$

0.358

0.336 $\begin{array}{rrrr}\text { Parameter } & \begin{array}{r}\text { Sign as } \\ \text { Estimate }\end{array} & \text { T for HO: } & \text { Prob }>|\mathrm{T}| \\ \text { Predicted? } & \text { Parm }=0 & \end{array}$

2.1956

$-0.0002$

$-177143$

33.4368

$-346.6351$

207.5793

$-0.7968$

20469
Yes

Yes

NO

?

Yes

NO

?
1.445

$-1.332$

$-3.049$

3.088

$-5.722$

5.141

$-6.635$

3.616
0.0001
0.0001

0.1499

0.1843

0.0026

0.0023

0.0001

0.0004 
Table 6: Results for Panel estimation, US outward only

$\begin{array}{lc}\text { Dependent variable: } & \text { RSALESF (weighted least squares) } \\ \text { Total observations } & 259 \\ \text { R-Squared } & 0.598 \\ \text { Adjusted R-Squared } & 0.585\end{array}$

$\begin{array}{lrrrr}\text { Variable } & \begin{array}{r}\text { Parameter } \\ \text { Estimate }\end{array} & \begin{array}{r}\text { Sign as } \\ \text { Predicted? }\end{array} & \begin{array}{r}\text { T for } \mathrm{HO}: \\ \text { Parm }=0\end{array} & \text { Prob }>|\mathrm{T}| \\ \text { GDPJ } & 6.8947 & \text { Yes } & 5.690 & 0.0001 \\ \text { GDPDIFSQ } & -0.0006 & \text { Yes } & -4.615 & 0.0001 \\ \text { SKDIFF } & -237383 & \text { No } & -4.803 & 0.0001 \\ \text { GDPDIFF*SKDIFF } & 44.7907 & ? & 4.860 & 0.0001 \\ & & & & \\ \text { INVCJ } & -211.3208 & \text { Yes } & -4.541 & 0.0001 \\ \text { TCJ } & -8.6449 & \text { Yes } & -0.279 & 0.7805 \\ & & & & \\ \text { DIST } & -8.6449 & ? & -3.001 & 0.0030 \\ \text { INTERCEPT } & 29941.00 & & 6.715 & 0.0001\end{array}$


Table 7: Results for Panel estimation, US outward only

Dependent variable: RATIOUSL (weighted least squares)

Total observations 231

R-Squared

0.413

Adjusted R-Squared

0.392

Variable

Parameter

Sign as

Estimate

Predicted?

T for HO:

Prob $>|\mathrm{T}|$

Parm $=0$

GDPJ

GDPDIFSQ

$-0.000693$

Yes

$-3.708$

0.0003

$-4.12 \mathrm{E}-08$

Yes

$-2.134$

0.0340

SKDIFF

2.364984

Yes

0.391

0.6963

GDPDIFF*SKDIFF

$-0.000186$

?

$-0.165$

0.8689

INVCJ

$-0.019319$

Yes

$-2.831$

0.0051

TCJ

$-0.004806$

Yes

$-0.959$

0.3387

DIST

0.000087

?

6.225

0.0001

INTERCEPT

1.947083

2.925

0.0038

Table 8: Results for Panel estimation, US outward only

Dependent variable:

Total observations

R-Squared

Adjusted R-Squared

Variable

GDPJ

GDPDIFSQ

SKDIFF

GDPDIFF*SKDIFF

INVCJ

TCJ

DIST

INTERCEPT
RATIOFL (weighted least squares) 236

0.343

0.320
Parameter

Estimate

$-0.001291$

$-2.36 \mathrm{E}-08$

29.904477

$-0.005218$

$-0.045391$

$-0.003751$

$-0.000026$

3.913419
Sign as

Predicted?

Yes

Yes

Yes

?

Yes

Yes

?
$\mathrm{T}$ for $\mathrm{HO}$ :

Parm $=0$

$-3.881$

$-0.683$

2.630

$-2.467$

$-3.517$

$-0.403$

0.0005

0.6876

$-0.841$

3.330
0.0001

0.4953

0.0091

0.0144

0.4014

0.0010 
Table 9: Effects of Host-Country Size and Skilled-Labor Abundance on Foreign Affiliate

Production for Local Sale and Export (derviatives evaluated at the mean of independent variables)

$\begin{array}{lllll} & \text { \$1 billon } & \text { One percentage } & \text { One point } & \text { One point } \\ \text { increase in } & \text { point increase in } & \text { increase in } & \text { increase in } \\ \text { Effect on: } & \text { country j's GDP } & \text { SKLJ* } & \text { INVCJ } & \text { TCJ }\end{array}$

\begin{tabular}{|c|c|c|c|c|}
\hline $\begin{array}{l}\text { Local sales of country i } \\
\text { affiiates in country j } \\
\text { (inward and outward data) }\end{array}$ & $\begin{array}{l}\$ 16.7 \text { million } \\
\varepsilon=1.558 \text { ** }\end{array}$ & $\begin{array}{c}-\$ 12.1 \text { million } \\
\varepsilon=-0.017\end{array}$ & - \$633.4 mill & \$366.6 mill \\
\hline $\begin{array}{l}\text { Export sales of country } i \\
\text { affiliates in j to all countries } \\
\text { (inward and }\end{array}$ & $\begin{array}{l}\$ 4.7 \text { million } \\
\varepsilon=1118\end{array}$ & $\begin{array}{c}-\$ 189.0 \text { million } \\
\varepsilon=-0681\end{array}$ & - \$277.2 mill & $\$ 52.1$ mill \\
\hline
\end{tabular}

Local sales of US

affiliates in country j

(US outward data only)

Export sales of US

affliliates in $\mathrm{j}$ to the US

(US outward data only)

Export sales of US

affliliates in $\mathrm{j}$ to other

(US outward data only)
$\$ 22.7$ million
$\varepsilon=1.044$

$\$ 280.5$ million

$\varepsilon=0.599$

- \$517.8 mill

$\$ 314.8$ mill

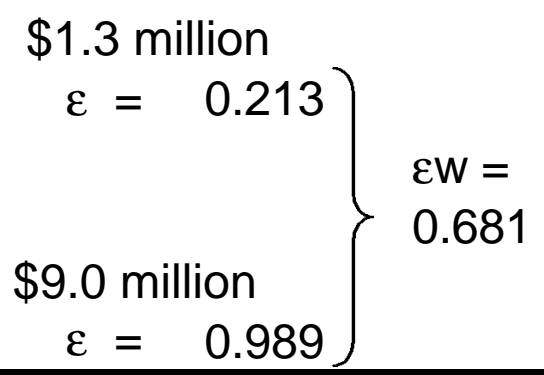

$\$ 8.3$ million

$\varepsilon=0.064$ $\varepsilon \mathrm{W}=$

0.062

* By a one-percentage-point increase in SKLJ we mean, for example, an increase from $15 \%$ to $16 \%$, not an increase from $15 \%$ to $15.15 \%$

${ }^{* *} \varepsilon$ denotes elasticity 
Figure 1: World Affiliate Sales

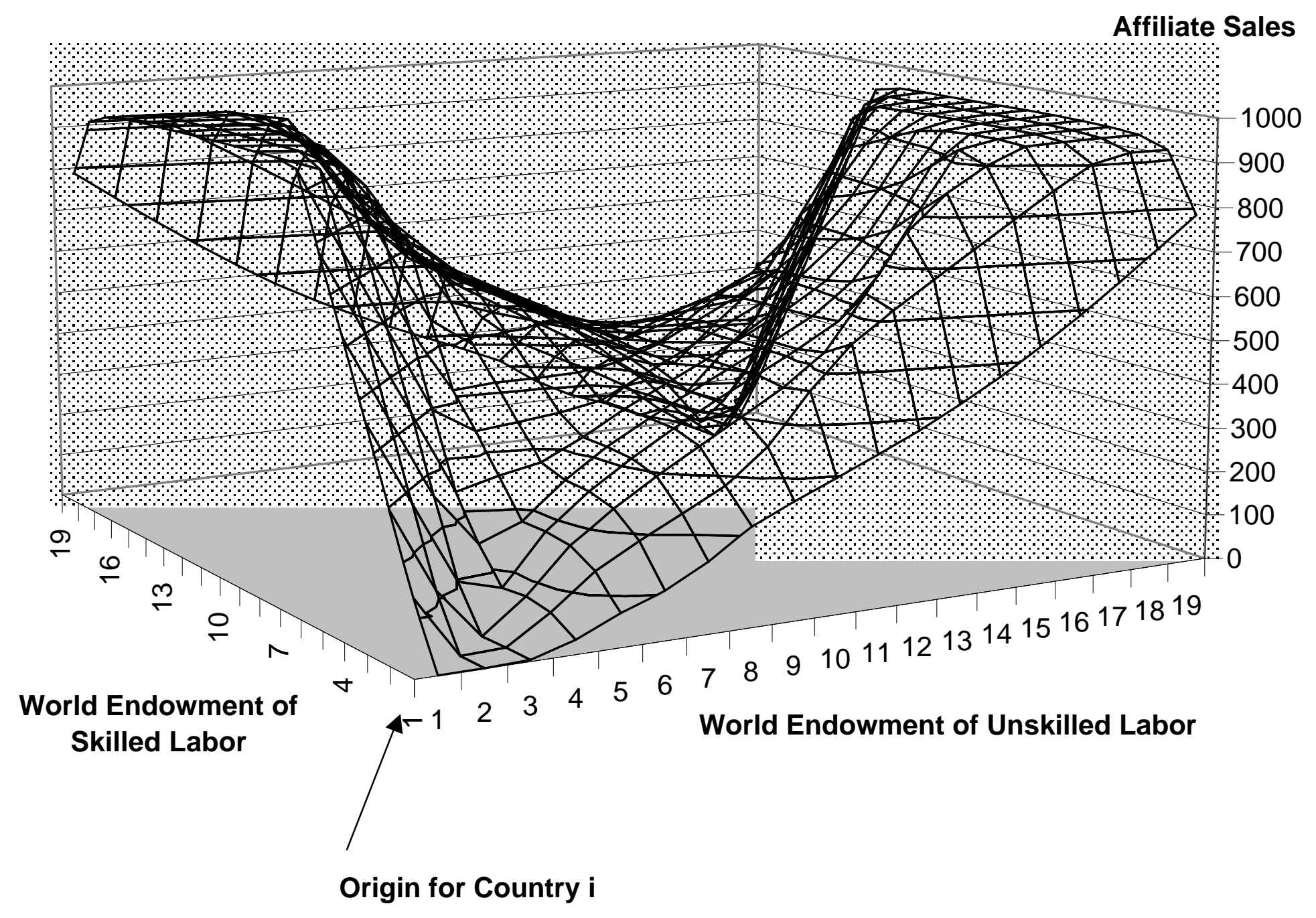


Figure 2: Local Sales of Affiliates of Country i firms in Country $j$

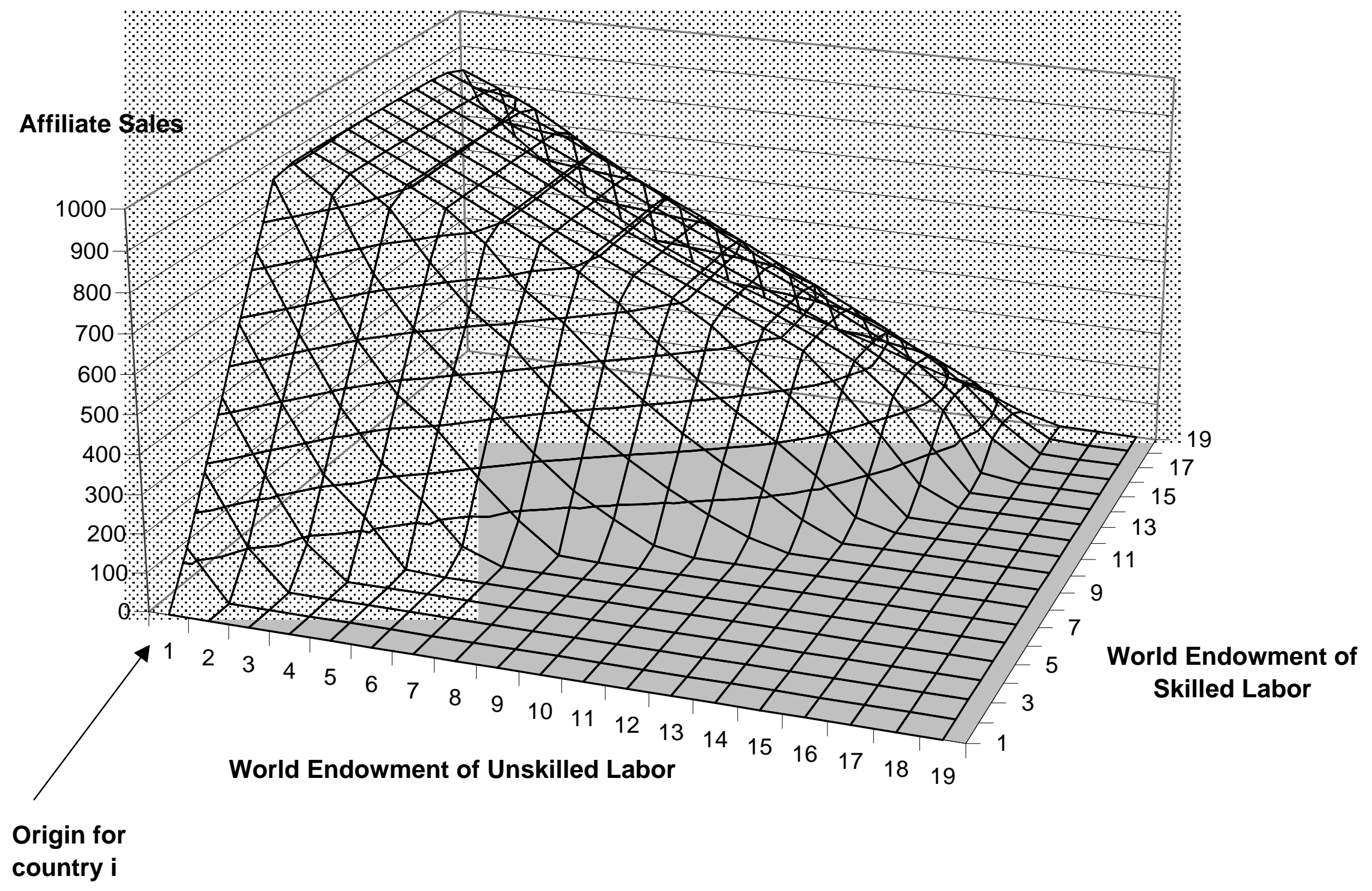




\section{Figure 3: Export Sales of Affiliates of Country i Firms in Country j}

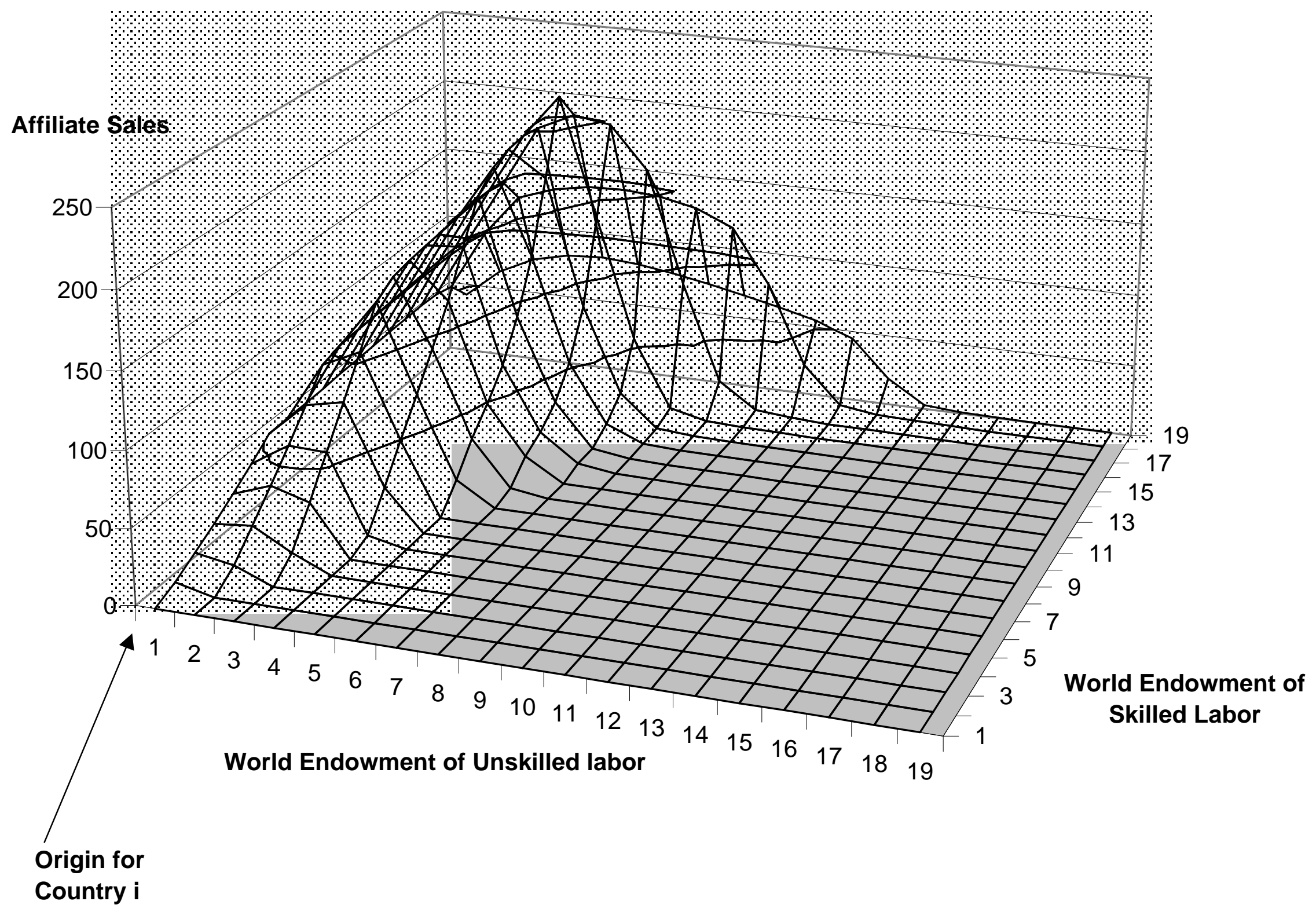


Figure 4: Ratio of Export Sales to Local Sales, Affiliates of Country i Firms in Country j

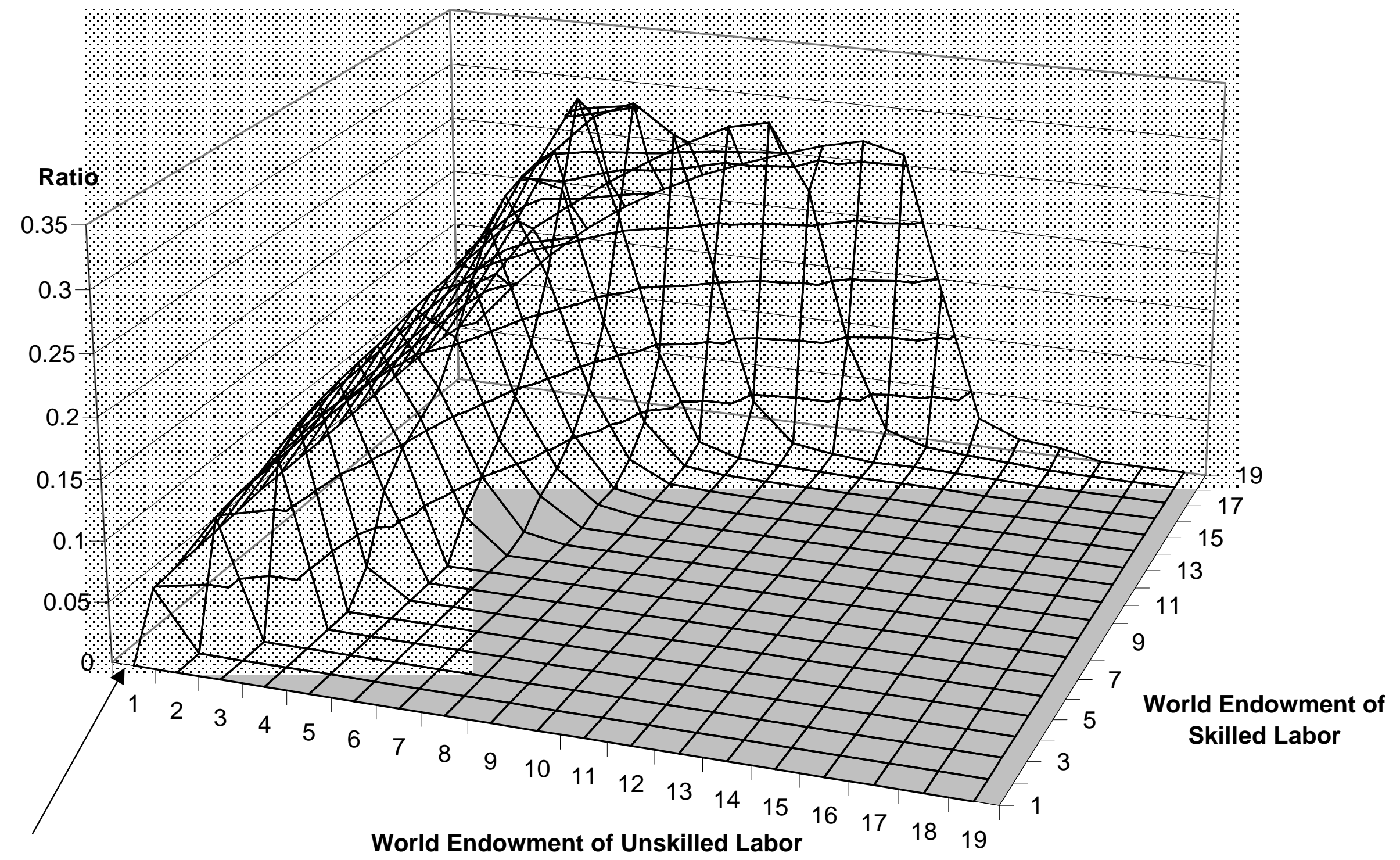

Origin for

Country i 